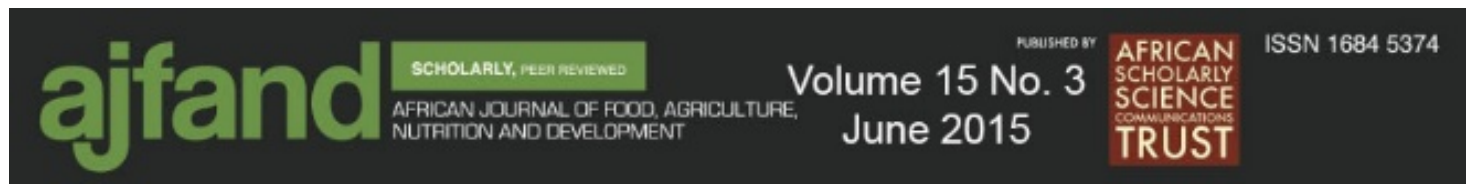

RURAL AFRICAN WOMEN'S ACCESSIBILITY TO RESOURCES FOR FOOD PRODUCTION IN THE NORTH WEST REGION OF CAMEROON

\title{
Fon $\mathrm{DE}^{1^{*}}$
}

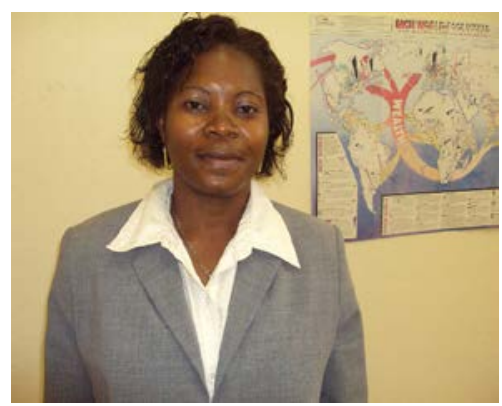

Dorothy Engwali Fon

*Corresponding author email: dengwali@yahoo.fr

${ }^{1}$ University of Dschang, Department of Agricultural Economics P.O. Box 222, Dschang, West Region, Cameroon. 


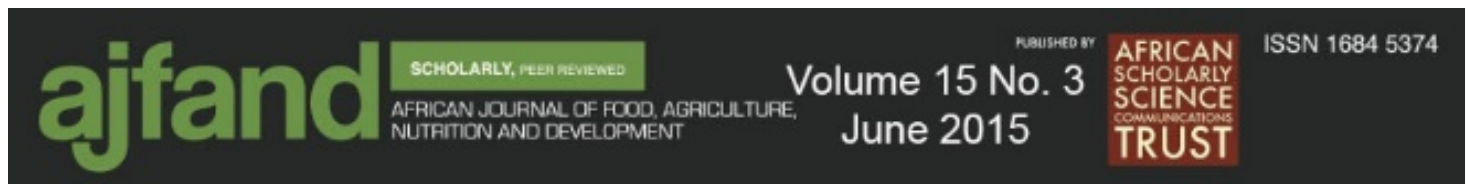

\begin{abstract}
Globalization has made agriculture more competitive in a way that access to and control of farm resources is extremely important. This study examines rural women's access to farm resources in arable small-scale food production in the North West Region of Cameroon. Using a multistage sampling technique a total of 1,120 rural women farmers were surveyed in order to capture their socioeconomic characteristics and access to arable land, agricultural inputs, agricultural extension information and source of finance and involvement in food production in smallholder production systems. All data collected was subjected to descriptive statistics. The results showed that rural women have access to arable land through their families but they do not control arable land. They have access to agricultural inputs but lack rural feeder roads and access to agricultural extension information and/or services. Rural women farmers lack finances and mostly access finance for arable agriculture from traditional social groups and their husbands to solve additional constraints of poor soils, pests and diseases. The rural women are involved in major crop production activities (land preparation (ploughing/ridging), sowing, weeding, harvesting and storage) which necessitate access to and control of farm resources but have limited access to resources in order to be efficient and competitive. Because of limited control of farm resources, they are not involved in decision-making, which usually translates into lateness in carrying out farm operations and consequently low yields. Access to land resources by rural women is controlled by cultural and technical factors. Boosting crop production will require that efforts are made socially and technically to remove the afore-mentioned barriers in the acquisition of farm resources. Therefore, agricultural production policies and programs should establish direct linkage between agricultural extension information and/or services, and rural women farmers, and provide incentives to rural women involved in arable small-scale agricultural production in order to maintain a steady growth rate of food production.
\end{abstract}

Key words: Women, access, inputs, finance, services 


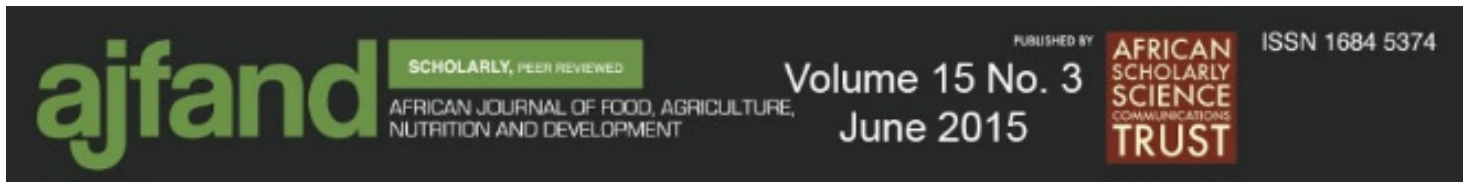

\section{INTRODUCTION}

Agriculture constitutes the main source of livelihood and employment opportunity for most people in Africa, Asia, and Latin America [1]. In Africa, it serves as the major source of income for approximately $70-80 \%$ of the population [2]. Renowned for its agrarian economy, Cameroon's agricultural production represents the main source of revenue for the government, with substantial contribution (20.7\%) to the Gross Domestic Product (GDP) [3]. Crops and livestock which contribute to the GDP are mainly but not limited to coffee, cocoa, rubber, bananas, oilseed, cereals, root starches, cattle, sheep and goats. Between 50 and $70 \%$ of the GDP contributed by agriculture comes from smallscale farmers who are mostly women (50-55\%). The importance, therefore, of women and their role in sustainable small-scale arable farming and the sustenance of food security and income generation, cannot be overemphasized. The intensification of activities in food production by these women is attributed to the sudden shift from the agricultural sector to non-farming wage employment by a majority of the male household heads. As a consequence of this, women are confronted with making challenging decisions in their farming enterprises in addition to other responsibilities such as household maintenance, preserver of matrimonial ties, chaperon of children's education, and custodian of family matters $[4,5]$. The prolonged absence of male labour from their respective households has adversely impacted land preparation in particular $[6,7]$.

Women contribute to all household expenses, and in Nigeria a man does not shoulder all or not more than half of the financial responsibilities at home [8,9]. Effective and efficient execution of household and farm roles by women requires quick access to farm and off-farm resources, which is usually not the case because of social and technical constraints. For example, it is argued that agricultural projects typically bypass or undercut women in the allocation of extension information and services, inputs (fertilizers, seeds) and credit [10]. The lack of recognition of women's contribution to agricultural development programs is attributed to the perceived dependent status of women as supplementary caretakers of homes and children, and as service providers. These attributes conceal women's contributions to the household and community. The above discussion suggests a need to look at agricultural policies as they can influence rural women's participation in small-scale arable farming.

The purpose of this study is to assess rural African women's accessibility to resources for food production in the North West Region of Cameroon. Specifically, this study seeks to determine the extent to which the rural women of the study area access arable smallscale sustainable land; acquire agricultural input; obtain agricultural extension information and /or services; their sources of finance and involvement in agricultural food production and to identify constraints encountered by women in arable small-scale and sustainable agriculture.

\section{METHODOLOGY}

\section{Study population, unit of analysis and sampling technique}

The study population composed of rural women involved in arable small-scale agriculture in the North West Region of Cameroon. The rural women are specifically 
defined as those who depend solely on arable small-scale farming for their livelihood. A multistage stratified random sampling was used for the study. The multistage stratified random sampling procedure involved the following: in stage one, there was a random selection of four divisions out of a total of seven divisions that comprise the North West Region of Cameroon. The four randomly chosen divisions include Bui, Donga Mantung, Mezam, and Momo. In stage two, two subdivisions were selected at random from each of the four chosen divisions. This brought the study area to eight subdivisions (Jakiri, Mbven, Ndu, Nwa, Bafut, Tubah, Batibo and Ngie). In stage three, four villages were randomly selected from each of the subdivision initially selected. This brought the total number of villages to thirty-two (32) The final villages were: Kimar, Sop, Wainamah, Yer, Lam, Mumyu, Reh, Rifem, Ndu, Njimnkang, Ntumbaw, Talla, Mbem, Ntong, Nwa, Sih, Bambili, Bambui, Big Banbanki, Small Banbanki, Mambu, Manji, Nchum, Nforya, Efah, Guzang, Mbunjei, Oshum, Bonatu, Ebang, Etwii and Teze . In stage four, thirtyfive (35) respondents were randomly selected from each of the thirty-two (32) villages. This gave a total sample size of 1,120 respondents. However, there were 1,118 completely filled and returned questionnaires representing $99.82 \%$. The unit of analysis was the individual rural woman of the North West Region who participated in this study.

\section{Validity and Reliability of Survey Instrument}

The instrument used in this study consisted of a list of questions developed following an extensive review of the literature on rural women's role in the household and economic activities in Cameroon. The questions were carefully phrased to ensure consistency of inquiry. The researcher issued the questionnaire to an odd numbered committee of experts for possible clarity, relatedness, and evaluation (for validity). The questionnaire consisted of eight subheadings with varied number of items under each subheading. The responses from the experts were re-examined to ascertain that questionnaire items reflected the intent of the questionnaire. The evaluation form was a Likert scale type (ranging from one to five) where 5 is very good, 4 is good, 3 is average, 2 is poor, and 1 is unusable. Those questions with commonalities were maintained while those that disagreed were thrown out. Thus, it was after all the copies cross-examined by the experts had been scrutinized, compared and the appropriate corrections made, that, content validity was established.

The questionnaire was pre-tested with 20 randomly selected women of the population to discern the extent to which the instrument was readable and understandable. The pretested questionnaires information was keyed into the computer; utilizing the Statistical Packages for the Social Sciences (SPPS) software, the Alpha Cronbach coefficient was calculated. Cronbach Alpha reliability coefficients for the variables of interest were significant enough to show consistency of the scores and the precision of the instrument. An Alpha Cronbach coefficient of 0.60 or more was considered acceptable. These Cronbach Alpha test scores suggest that the items on the survey had a moderate to high level of internal consistency, and hence the survey instrument was considered acceptable for use in collecting the data for this study.

\section{Data collection and analysis}

Data were obtained from primary sources. The primary data were collected using a set of structured and pre-tested questionnaires, which were administered to the rural women 
farmers of the study area. Combinations of both open and close-ended questions were used. The technique of data collection was reactive. In administering the questionnaire, the researcher was assisted by well-trained indigenous females from the study area to avoid the problem of language barrier and unforeseeable cultural norms of a male trainee being close to the females. The enumerators were females from the study area because the rural women of the North West Region of Cameroon are more fluent in their dialects. This was to ensure that the women would feel more comfortable answering the questions sincerely to someone who is their gender. The questionnaire provided information on personal and socioeconomic characteristics of the women, their access to arable smallscale sustainable land, access to agricultural input, access to agricultural extension information and/or services, and source of finances and involvement in arable smallscale sustainable agricultural production. The problems encountered by rural women farmers in arable agriculture were also obtained from the survey. The data collected were subjected to descriptive statistics.

\section{RESULTS}

The sources of land are family, renting, as a gift, soliciting and communal land. The results (Table 1) indicate that a large majority (68-74\%) of the rural women were of the opinion that access to arable small-scale sustainable land was mostly from family and from soliciting, while the next major group of the women (53\%) were of the opinion that their primary source of land for arable small-scale sustainable land was as a gift. Only a few of the rural women were of the opinion that they accessed arable small-scale sustainable land from renting and communal land.

\section{Rural Women's Access to Small-Scale Sustainable Agricultural Input}

The agricultural inputs that were studied were chemical fertilizer and manure. Table 2 indicates that a majority (69\%) of rural women have access to chemical fertilizers. A large majority (91\%) of the rural women have access to manure of which a sizable proportion (58\%) of rural women has access to cow dung as manure. Only a third (31\%) of the rural women in the study area indicated not having access to chemical fertilizers and less than $10 \%$ have no access to manure.

\section{Rural Women's Access to Small-Scale Sustainable Agricultural Extension Information and/or Services}

Information is an essential production factor in agriculture. Farmers need relevant and timely information to improve their production techniques and increase their income. Rural women farmers have various channels of communication through which they receive advice on agricultural production matters, namely agricultural extension officer or agent, friend, relative, meeting house and church. Meeting houses and churches are informal channels through which rural women access information and /or services concerning arable agriculture. Such pieces of information and /or services are geared toward improving their farming techniques or acquiring new agricultural production techniques (seed treatment methods) and agricultural production materials like seeds.

Table 3 presents the results of the rural women's opinion about their level of access to agricultural extension information and/or services in the North West Region of 


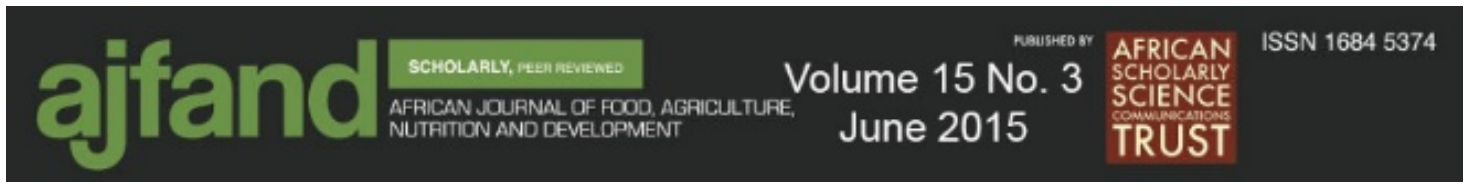

Cameroon.The table indicates that a majority (53\%) of the women were of the opinion that they did not have access to extension information and/or services.

\section{Financing Small-scale Sustainable Agriculture}

Financing for arable agriculture is derived from various sources including husband, relative, friend, njangi (traditional social group), cooperative, credit union, bank and government. Table 4 presents the frequency distribution of rural women according to their sources of financing in arable agriculture. The table shows that a majority of the rural women ranked their sources of finance as njangi (85 \%), friend (59\%), husband (58\%), and relative (54\%); while credit union, cooperatives and banks were the least source of finance for arable agriculture.

\section{The Extent of Rural Women's Involvement in Agricultural Production Activities}

Table 5 displays the distribution of rural women farmers in the study area according to the extent of their involvement in farm activities. The table shows that more than $50 \%$ of the rural women farmers in the study area significantly contributed labour on a regular basis in all areas of farming (land clearing, staking, ploughing/ridging, sowing, weeding, harvesting, transporting, storage, processing and commercializing).

\section{Problems Faced by Rural Women Farmers in Farm Activities}

The problems encountered in arable small scale sustainable agriculture in the study area in order of importance suggests that lack of finances, lack of rural feeder roads, poor soils and pests and diseases were some of the worst problems encountered by rural women farmers in the study area. High cost of farm inputs, poor yield of agricultural food crops, and scarcity of farm inputs were serious problems encountered by rural women farmers. Other problems identified by the respondents included poor seed germination, erosion, transportation of agricultural produce from the farm to the homestead, low cost of agricultural food produce, and marketing of agricultural produce. Theft, scarcity of labour, high cost of acquiring arable land, and unreliable hired labour were not considered as problems.

\section{DISCUSSIONS}

The results on access to arable land for small-scale sustainable agriculture indicate that the prevailing pattern of land accessibility could be due to socio-cultural or land tenure practices in the study area. It was recognized from the World Bank policy research report that in much of Sub-Saharan Africa, women obtain land rights chiefly through their husbands as long as the marriage endures [11]. The study found that rural women farmers in the study area, generally, do not have access to arable land for small-scale sustainable agriculture. This finding is consistent with previous findings that divorced women nearly always lose access to their ex-husband's land [12, 13]. This may be a reflection of the paternalistic nature of the culture of Cameroon and most developing countries where women have minimal roles in economic decision making.

Based on the findings of the extent of access to agricultural extension information and/or services, it could be argued that agricultural extension agents could lose the confidence of rural women farmers due to lack of proper communication and inability to adequately 
convey extension information effectively to them. It is assumed that rural women farmers' access to agricultural extension information and/or services and their ability to comprehend technical information are lower when they lack the minimum formal education. Moreover, because of illiteracy, rural women farmers are less able to understand written extension materials.

The finding that njangi is the major source of finance for small-scale arable agricultural production from this study is consistent with the finding that in Cameroon njangi is a very important source of raising capital [4]. The study's finding that more than 50 percent of the rural women farmers in the study area significantly contributed to labour on a regular basis in all areas of farming (land clearing, staking, ploughing/ridging, sowing, weeding, harvesting, transporting, storage, processing, and commercializing) is consistent with the literature that there are no gendered agricultural production activities in recent times. No agricultural production activity is shared equally by men and women. The high percentage of rural women farmers (61\%) involved in land clearing is consistent with previous findings that the gender specific nature of African farming is disappearing as women are taking on tasks such as land clearing which was traditionally performed by men [14].

It was not surprising that hired labour and high cost of acquiring land were not serious major problems because rural women farmers mostly relied on family labour or during peak seasons hired labour from other families or villages or hired seasonal farm workers, particularly for land preparation, cultivation, harvesting and processing of their crops [2]. Spoilage of produce was not a major problem since most of the respondents reported having been involved in food processing. This is consistent with the Food and Agricultural Organization reports that women carry out most of the food processing activities [15].

In summary, there are many areas of the economy in which rural women play vital but officially ignored roles, thus very little data is available to inform policymakers. Collecting gender-desegregated information is a first step toward developing gender responsive policies and programs. The agricultural crop production sector remains the major source of food for most Sub-Sahara African countries. The bulk of agricultural production processes are carried out by women, but they have the least access to those resources that lead to the final output. The non recognition of women's contributions to the agricultural crop production sector makes them invisible to planners and policy makers.

\section{CONCLUSION}

Based on the results, the following major conclusions can be gleaned from this study: Sources of arable land for small-scale sustainable agricultural production include family, soliciting and as a gift. Rural women farmers have access to all types of agricultural inputs (chemical fertilizers, and manure), with a large proportion (91\%) of the women having access to manure especially cow dung. Most (53\%) rural women do not have access to agricultural extension information and/or services. Most (85\%) rural women farmers accessed financing for small-scale sustainable agriculture from njangi 
(traditional social group) and husbands. Rural women farmers in the study area, on the average, are involved to a large extent in all the different farm operations/activities, but more involved in ploughing/ridging, sowing, weeding, harvesting and storage. Rural women farmers of the North West Region of Cameroon encountered problems of lack of funds, lack of rural feeder roads, poor soils, pests and diseases, high cost of farm inputs, poor yield of agricultural food crops and scarcity of some farm inputs.

\section{RECOMMENDATIONS}

Access to agricultural production resources, input and services is essential to elevate the rural poor women from perpetual economic doldrums and encourage them to contribute to sustainable human development.

Expanding access to essential agricultural production resources requires attention to policy changes. Agricultural policies, particularly in Cameroon and developing countries in general, are not always fully attuned to ensuring that agricultural resources are available, affordable, or appropriate. Solutions must begin with an understanding of local agricultural conditions. There should be a participatory approach to agricultural development (farmer participation rather than mere involvement) in decision-making, implementation, and evaluation. This is critical because of their experiences and proximity to the many challenges. Local farmers live more closely to the real problems, constraints, and opportunities afforded by the environment.

Development strategies and programs, as well as incentives programs and projects, in the field of food and agricultural production should be designed in a manner that fully integrates women at all levels of planning, implementation, monitoring and evaluation in all stages of the development process. Such integration would facilitate and enhance this key role of women and would ensure that women receive proper benefits and remuneration, commensurate with their contribution to agricultural food production field.

A professional consultation should begin between policy makers and bureaucrats on the issue of rural women's access to agricultural resources. A policy enactment, as a consequence of consultation, implies that all concerned should be trained. For example, there should be implementation of agricultural training programs for rural women geared towards preparing them on the utilization of agricultural inputs like chemical fertilizers.

\section{Limitations and Prospects for Future Research}

In this study, the target population was rural women of the North West Region of Cameroon who are engaged in agricultural/food production related roles for livelihood. In addition, the sources of data were limited to the respondents. This study was a case study of the rural women of the North West Region of Cameroon regarding their access to productive resources in agricultural production. This type of study has three major limitations [16]. First, there is complete absence of control, and only rural women of the Northwest Region of Cameroon participated in this study, thus limiting the external validity of the study's findings. Second, there was no provision for comparison, which is the basis of science, except implicitly and intuitively. Third, this approach to inquiry usually involves the "error of misplaced precision" in that a great deal of time is devoted 


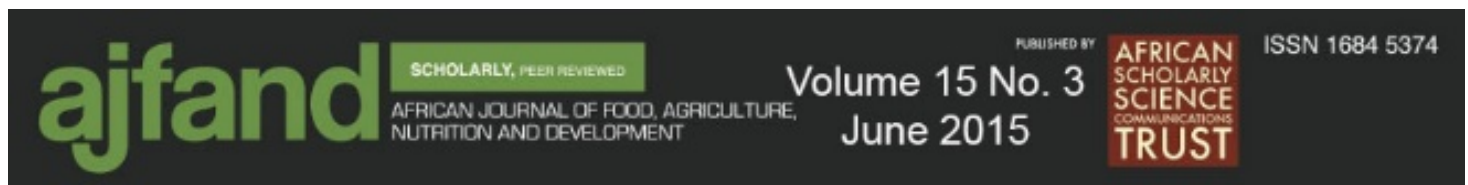

to the collection of data about which the conclusion derived can only be impressionistic and imprecise. These limitations imply that interpretation or generalization of the findings of this study should be made to populations with similar characteristics.

Acknowledgements: The author is grateful to the Mississippi Consortium for International Development (MICD) for providing the financial assistance for this research work. 


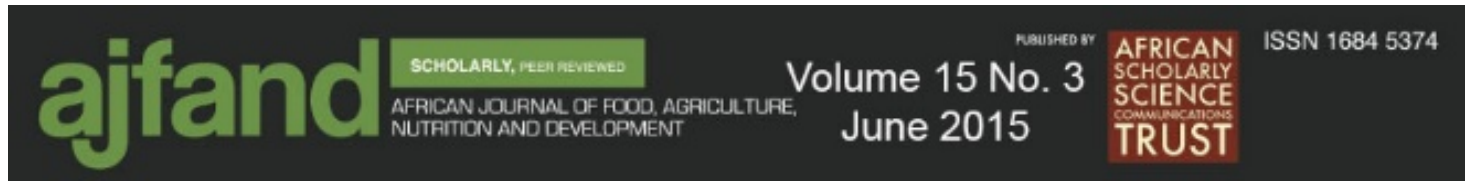

Table 1: Frequency Distribution of Sources of Rural Women's Access to Arable Land for Small-scale Sustainable production

\begin{tabular}{|c|c|c|c|c|c|}
\hline \multirow[b]{2}{*}{ Source } & \multicolumn{2}{|c|}{ Not a Source of Land Access } & \multicolumn{3}{|c|}{ Source of Land Access } \\
\hline & Frequency & $\%$ & Frequency & $\%$ & $\mathrm{~N}$ \\
\hline Family & 288 & 25.80 & 830 & 74.20 & 1118 \\
\hline Renting & 688 & 61.50 & 430 & 38.50 & 1118 \\
\hline Gift & 530 & 47.50 & 587 & 52.50 & 1117 \\
\hline Soliciting & 362 & 32.30 & 756 & 67.70 & 1118 \\
\hline Communal & 871 & 78.00 & 245 & 22.00 & 1116 \\
\hline
\end{tabular}

Table 2: Frequency Distribution of Extent of Rural Women's Access to Chemical Fertilizer, cow dung and manure

\begin{tabular}{lcccccc}
\hline & & & \multicolumn{5}{c}{ Manure } \\
\cline { 4 - 7 } Response Category & \multicolumn{2}{c}{ Chemical fertilizer } & \multicolumn{2}{c}{ Cow dung } & \multicolumn{2}{c}{ Others } \\
\cline { 4 - 7 } & Number & $\%$ & Number & $\%$ & Number & $\%$ \\
\hline No Extent at all & 173 & 15.47 & 168 & 15.02 & 36 & 3.22 \\
No Extent & 174 & 15.56 & 334 & 29.88 & 62 & 5.55 \\
To Some Extent & 494 & 44.19 & 380 & 33.99 & 629 & 56.26 \\
To an Extent & 217 & 19.41 & 190 & 17 & 272 & 24.33 \\
To a Great Extent & 60 & 5.37 & 46 & 4.11 & 119 & 10.64 \\
\hline Total & 1118 & 100.00 & 1118 & 100.00 & 1118 & 100.00 \\
\hline
\end{tabular}




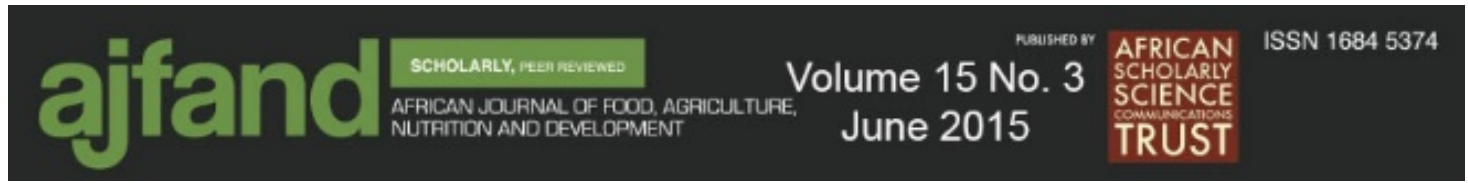

Table 3: Frequency Distribution of the Extent of Rural Women's Access to Agricultural Extension Information and /or Services

\begin{tabular}{lcc}
\hline Category & Frequency & Percent \\
\hline No Extent at all & 75 & 6.7 \\
No Extent & 514 & 46.0 \\
To some Extent & 450 & 40.3 \\
To an Extent & 78 & 7.0 \\
To a Great Extent & 1 & .1 \\
\hline Total & 1118 & 100.0
\end{tabular}

Table 4: Sources of Finance for Small-Scale Arable Farming by Rural Women

\begin{tabular}{|c|c|c|c|c|c|c|}
\hline \multirow[b]{2}{*}{ Source } & \multirow[b]{2}{*}{ Total } & \multicolumn{2}{|c|}{ Yes } & \multirow[b]{2}{*}{ Rank } & \multicolumn{2}{|c|}{ No } \\
\hline & & Frequency & Percentage & & Frequency & Percentage \\
\hline Husband & 1118 & 651 & 58.23 & $3^{\text {rd }}$ & 467 & 41.77 \\
\hline Relative & 1118 & 606 & 54.20 & $4^{\text {th }}$ & 512 & 45.80 \\
\hline Friend & 1114 & 659 & 59.16 & $2^{\text {nd }}$ & 455 & 40.84 \\
\hline Njangi & 1118 & 954 & 85.33 & $1^{\text {st }}$ & 164 & 14.67 \\
\hline Cooperative & 1118 & 102 & 9.12 & $6^{\text {th }}$ & 1016 & 90.88 \\
\hline Credit Union & 1118 & 341 & 30.50 & $5^{\text {th }}$ & 777 & 69.50 \\
\hline Bank & 1118 & 13 & 1.16 & $7^{\text {th }}$ & 1105 & 98.84 \\
\hline Government & 1118 & 0 & 0.00 & $8^{\text {th }}$ & 1118 & 100.0 \\
\hline
\end{tabular}




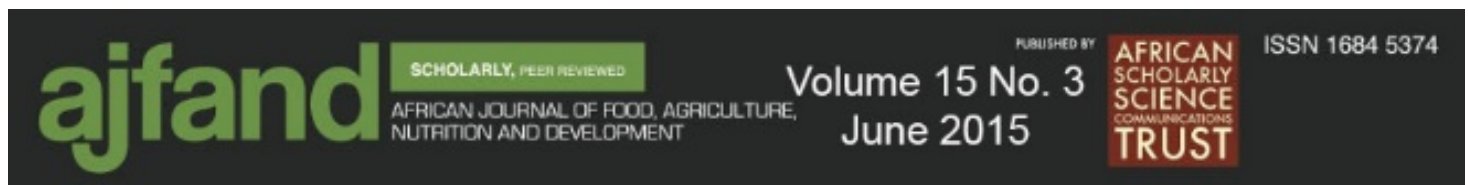

Table 5: Distribution of Rural Women's Involvement in Farm Operations/Activities

\begin{tabular}{|c|c|c|c|c|c|c|c|c|c|c|c|}
\hline \multirow[b]{2}{*}{ Activity } & \multicolumn{2}{|c|}{$\begin{array}{l}\text { Not } \\
\text { Involved } \\
\quad \text { at all }\end{array}$} & \multicolumn{2}{|c|}{$\begin{array}{l}\text { Not } \\
\text { Involved }\end{array}$} & \multicolumn{2}{|c|}{$\begin{array}{l}\text { Somewhat } \\
\text { Involved }\end{array}$} & \multicolumn{2}{|c|}{ Involved } & \multicolumn{3}{|c|}{$\begin{array}{l}\text { Very } \\
\text { Involved }\end{array}$} \\
\hline & Freq. & $\%$ & Freq. & $\%$ & Freq. & $\%$ & Freq. & $\%$ & Freq. & $\%$ & Total \\
\hline Land Clearing & 99 & 8.86 & 56 & 5.01 & 285 & 25.49 & 156 & 13.95 & 522 & 46.69 & 1118 \\
\hline Staking & 86 & 7.69 & 83 & 7.42 & 293 & 26.21 & 227 & 20.30 & 429 & 38.37 & 1118 \\
\hline Ploughing/ridging & 15 & 1.34 & 15 & 1.34 & 207 & 18.52 & 147 & 13.15 & 734 & 65.65 & 1118 \\
\hline Sowing & 37 & 3.31 & 15 & 1.34 & 201 & 17.98 & 191 & 17.08 & 674 & 60.29 & 1118 \\
\hline Weeding & 6 & 0.54 & 1 & 0.09 & 163 & 14.58 & 146 & 13.06 & 802 & 71.74 & 1118 \\
\hline Harvesting & 4 & 0.36 & 0 & 0.00 & 173 & 15.50 & 272 & 24.30 & 669 & 59.84 & 1118 \\
\hline Transporting & 8 & 0.72 & 1 & 0.09 & 278 & 24.87 & 356 & 31.84 & 475 & 42.49 & 1118 \\
\hline Storage & 6 & 0.54 & 11 & 0.98 & 238 & 21.29 & 285 & 25.49 & 578 & 51.70 & 1118 \\
\hline Processing & 41 & 3.67 & 89 & 7.96 & 262 & 23.43 & 269 & 24.06 & 457 & 40.88 & 1118 \\
\hline Commercializing & 37 & 3.31 & 85 & 7.60 & 282 & 25.22 & 249 & 22.27 & 465 & 41.59 & 1118 \\
\hline
\end{tabular}




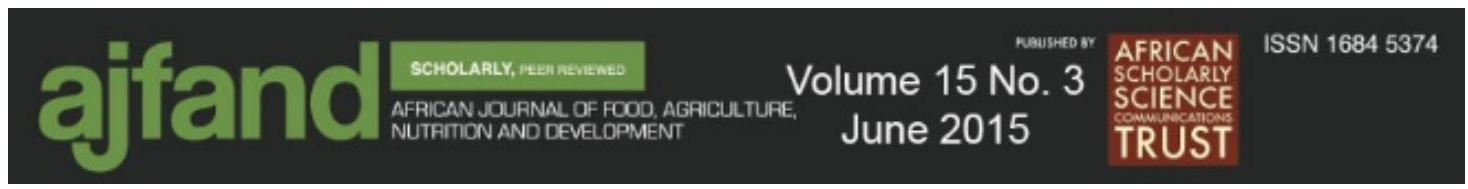

\section{REFERENCES}

1. Mies M "Indian Women in Subsistence and Agricultural Labour." Geneva, Switzerland: ILO Women, Work and Development 12, 1986.

2. Toulmin C and B Guèye "Is There a Future for Family Farming in West Africa?” In Small- Scale Farmers in Liberalized Trade Environment. Proceedings of the Seminar on October 2004 in Haikko, Finland, eds. T. Huvio, J Kola and T. Lundström, 2004: 53-73. Publication No. 38, Helsinki: Agricultural Policy.

3. Central Intelligence Agency (CIA) World Fact book Country file Cameroon, 2013 accessed from website https://www.cia.gov/library/publications/the-worldfactbook/geos/cm.html on 13/01/2014.

4. $\quad$ Fonchingong C "Structural Adjustment, Women and Agriculture in Cameroon." Gender and Development 7, no. 3, 1999:73-79.

5. Logo PB and HE Bikie "Women and Land in Cameroon: Questioning Women's Land Status and Claims for Change.” In Women and Land in Africa: Culture, Religion and Realizing Women's Right, ed. Muthoni L. Wanyeki, 2003:31-66 London: Zed Books Ltd.

6. Cotula L, Camilla T and Q Julian "Better Land Access for the Rural Poor: Lessons from Experience and Challenges Ahead (IIED, FAO), 2006.

7. James UV “Introduction: Sustaining Women's Efforts in Africa's Development.” In Women and Sustainable Development in Africa. ed. Valentine U. James, 1995:1-15. Westpoint, Connecticut: Praeger.

8. Nabulo G, Nasinyama G and H Oryem-Origa "The Role Of Women in Urban Food Production and Food Security in Kampala City, Uganda.” A paper presented at the Gender Mainstreaming in Urban Food Production and Food Security. Women Feeding Cities workshop. Accra, Ghana, 20-23 September, 2004.

9. Akinsanmi A "Working under Constraints: Women, Poverty and Productivity." Women and Environment no. 66/67, 2005: 17-18.

10. Blumberg RL Making the Case for the Gender Variable: Women and the Wealth and Wellbeing of Nations. Washington, D.C.: United States Agency for International Development, 1989.

11. World Bank. Gender and Development through Gender Equality in Rights, Resources and Voice. A World Bank Policy Research Report, 2000.

12. Goebel A Gender and Land Reform: The Zimbabwe Experience. Montreal \& Kingston: London McGrill-Queen University Press, 2005. 


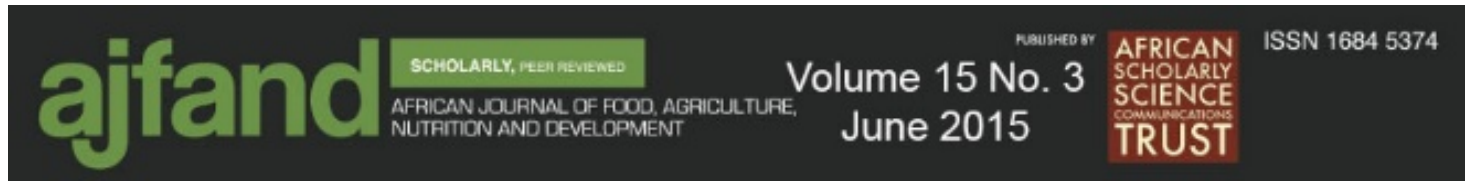

13. Koopman $\mathbf{J}$ “The Hidden Roots of the African Food Problem: Looking within the Rural Household," In The Women, Gender and Development Reader. Nalini Visvanathan (London), UK: Zed Books, 1997: 132-141.

14. Saito KA Raising the Productivity of Women Farmers in Sub-Sahara Africa. World Bank Discussion Paper No. 230, Washington, D.C.: World Bank, 1994.

15. FAO. “Gender: Key to Sustainability and Food Security, Plan of Action,” Gender and Development FAO, 2003.

16. Isaac S and BW Michael Handbook in Research and evaluation ( $3^{\text {rd }}$ edition) San Diego, California: EdITS, 1997. 